Supporting Information

\title{
High Triplet Energy Phosphine Sulfide Host Materials with Selectively Modulated Electrical Performance for Blue Electrophosphorescence
}

Huanhuan $\mathrm{Li}^{\dagger}$, Yunbo Jiang ${ }^{\dagger}$, Jun Wang ${ }^{\dagger}$, Yibin $\mathrm{Zhi}^{\dagger}$, Yizhong $\mathrm{Dai}^{\dagger}$, Ye Tao ${ }^{* *}$, Mingguang Li, Runfeng Chen ${ }^{* *}$, Chao Zheng ${ }^{\dagger}$, Wei Huang $*^{*}$

${ }^{\dagger}$ Key Laboratory for Organic Electronics and Information Displays \& Jiangsu Key Laboratory for Biosensors, Institute of Advanced Materials (IAM), Jiangsu National Synergetic Innovation Center for Advanced Materials (SICAM), Nanjing University of Posts \& Telecommunications, 9 Wenyuan Road, Nanjing 210023, China. \#nstitute of Flexible Electronics, Northwestern Polytechnical University, Xi’an, 710129, China.

Supporting information:

Number of Page: 20 (S1-S20)

Number of Scheme: 1 (Scheme S1)

Number of Figure: 21 (Figures S1-S21)

Number of Table: 3 (Tables S1-S3)

\section{Contents}

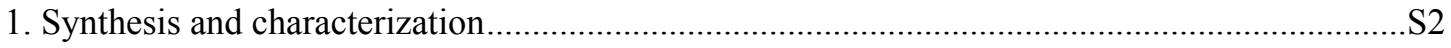

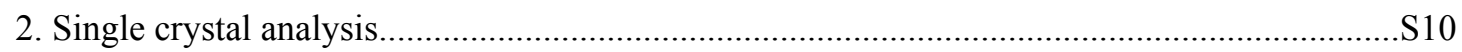

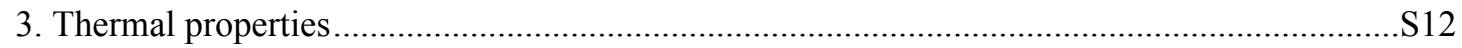

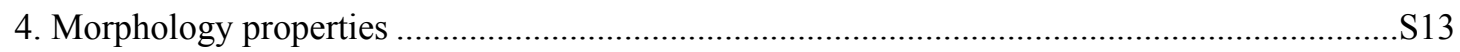

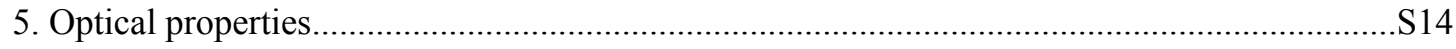

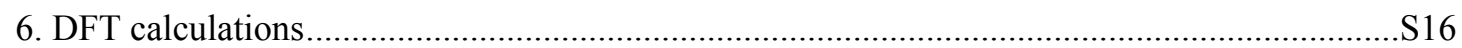

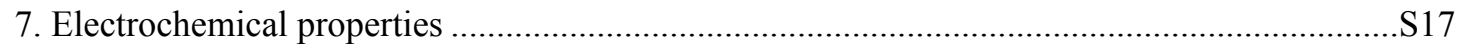

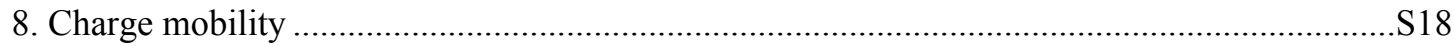

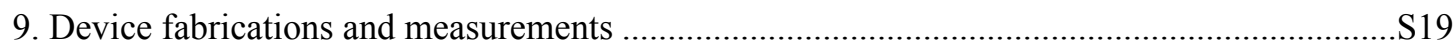




\section{Synthesis and characterization}

Materials: The manipulations involving air-sensitive reagents were performed in an atmosphere of dry Argon. The chemicals and solvents, unless otherwise specified, were purchased from Aladdin, Aldrich or Acros, and used without further purification. Tetrahydrofuran (THF) was dried and purified in a standard procedure.

Characterization methods: ${ }^{1} \mathrm{H}$ and ${ }^{13} \mathrm{C}$-nuclear magnetic resonance (NMR) spectra were recorded on a Bruker Ultra Shield Plus $400 \mathrm{MHz}$ instrument with $\mathrm{CDCl}_{3}$ as the solvent and tetramethylsilane (TMS) as the internal standard. The quoted chemical shifts are in ppm and the $J$ values are expressed in Hz. The splitting patterns have been designed as follows: s (singlet), d (doublet), $\mathrm{t}$ (triplet), dd (doublet of doublets) and $\mathrm{m}$ (multiplet). High-resolution mass spectroscopy (HRMS) were recorded on a LCT Premier XE (Waters) mass spectrometer. Melting point (Mp) was measured on a SGW X-4 micro melting point meter.

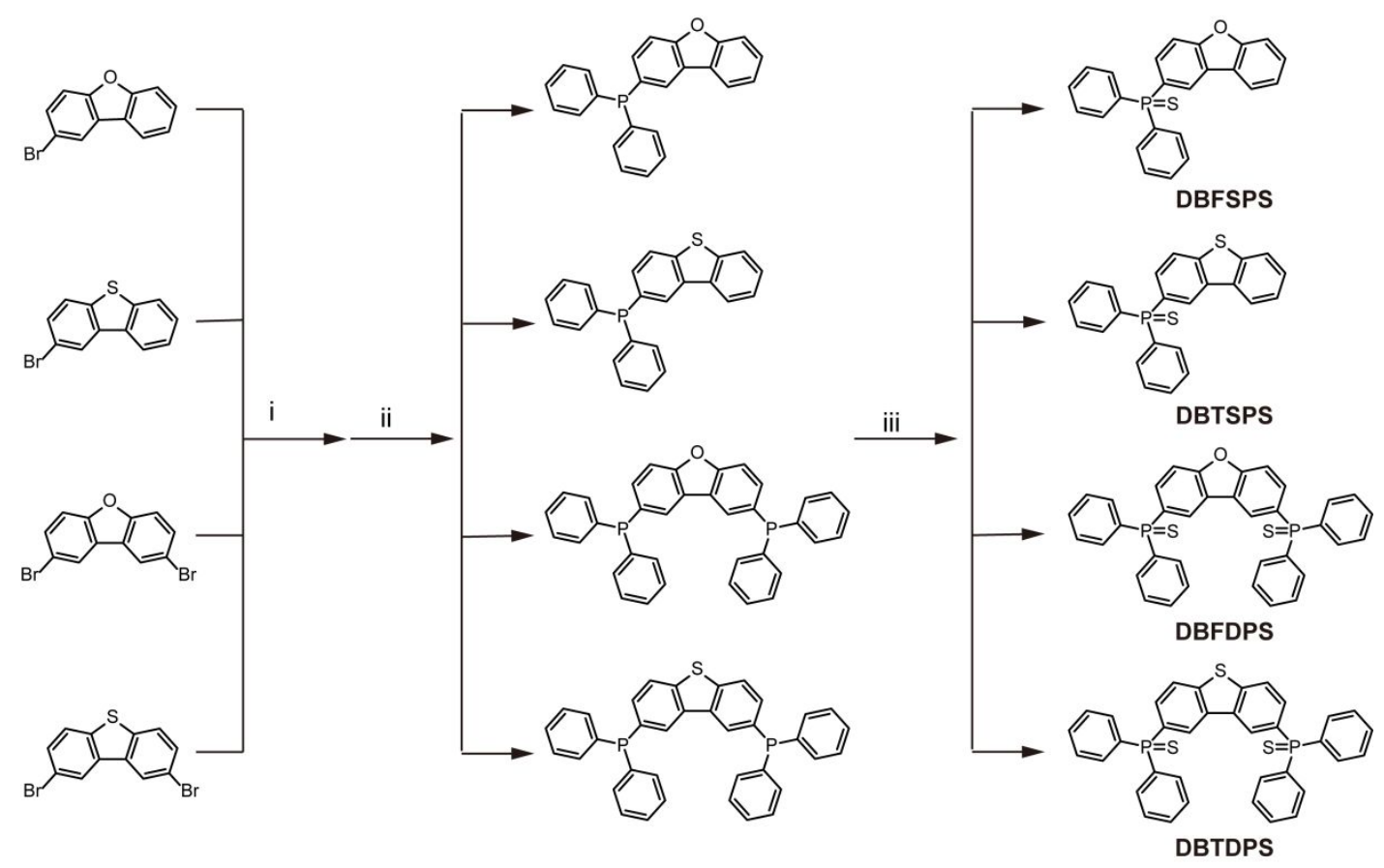

Scheme S1. The synthetic route of phosphine sulfide molecules (i) $n$-BuLi, THF, $-78^{\circ} \mathrm{C}, 2 \mathrm{~h}$; (ii) $\mathrm{Ph}_{2} \mathrm{PCl},-78^{\circ} \mathrm{C}, 1 \mathrm{~h}$; (iii) sulfur, $\mathrm{CH}_{2} \mathrm{Cl}_{2}$, room temperature, overnight.

\section{Synthesis of dibenzo[b, d]furan-2-yldiphenylphosphine sulfide (DBFSPS)}

2-bromodibenzo[b, d]furan $(2.5 \mathrm{~g}, 10.0 \mathrm{mmol})$ was dissolved in $100 \mathrm{~mL}$ of anhydrous THF under $\mathrm{Ar}_{2}$ and was cooled to $-78^{\circ} \mathrm{C}$ in a dry ice/acetone bath. $n$-Butyl lithium $(7.5 \mathrm{~mL}, 12.0 \mathrm{mmol}$, 
1.6 $\mathrm{M}$ in hexane) was then added dropwise to give a bright yellow solution. After reaction for $2 \mathrm{~h}$, $2.0 \mathrm{~mL}$ of diphenylphosphine chloride $(10.8 \mathrm{mmol})$ was added to the system at $-78^{\circ} \mathrm{C}$ and then at room temperature overnight. The reaction was quenched with water $(40 \mathrm{~mL})$ and extracted by dichloromethane $(3 \times 50 \mathrm{~mL})$. The organic layer was collected and dried with anhydride $\mathrm{Na}_{2} \mathrm{SO}_{4}$. After the evaporation of the solvent, the solid resides was dissolved in dichloromethane $(50 \mathrm{~mL})$ for sulfurization by adding sulfur $(1.0 \mathrm{~g}, 30 \mathrm{mmol})$. After stirred overnight at room temperature, then the evaporation of the solvent and purified by column chromatography. Yield: $1.6 \mathrm{~g}$ of white powder (42.1\%). Mp: $122^{\circ} \mathrm{C} .{ }^{1} \mathrm{H}$ NMR $\left(400 \mathrm{MHz}, \mathrm{CDCl}_{3}, \mathrm{ppm}\right) \delta 8.66(\mathrm{~d}, J=16.0 \mathrm{~Hz}, 1 \mathrm{H}), 8.12(\mathrm{~d}, J=$ $4.0 \mathrm{~Hz}, 1 \mathrm{H}), 7.91(\mathrm{~d}, J=12.0 \mathrm{~Hz}, 1 \mathrm{H}), 7.88(\mathrm{~d}, J=8.0 \mathrm{~Hz}, 1 \mathrm{H}), 7.78(\mathrm{dd}, J=12.0 \mathrm{~Hz}, 4 \mathrm{H}), 7.70$ $(\mathrm{dd}, J=15 \mathrm{~Hz}, 1 \mathrm{H}), 7.54(\mathrm{~m}, 8 \mathrm{H}) ;{ }^{13} \mathrm{C} \mathrm{NMR}\left(100 \mathrm{MHz}, \mathrm{CDCl}_{3}, \mathrm{ppm}\right) \delta 143.20,139.62,135.77$, $135.64,134.80,133.59,132.37,132.26,131.68,131.65,129.56,129.44,129.07,128.69,128.56$, 128.21, 127.52, 126.17, 126.05, 124.87, 122.88, 122.86, 122.72, 122.11; HRMS (EI): m/z calcd for $\mathrm{C}_{24} \mathrm{H}_{17} \mathrm{OPSK}[\mathrm{M}+\mathrm{K}]^{+}:$423.0375; found: 423.0399 .
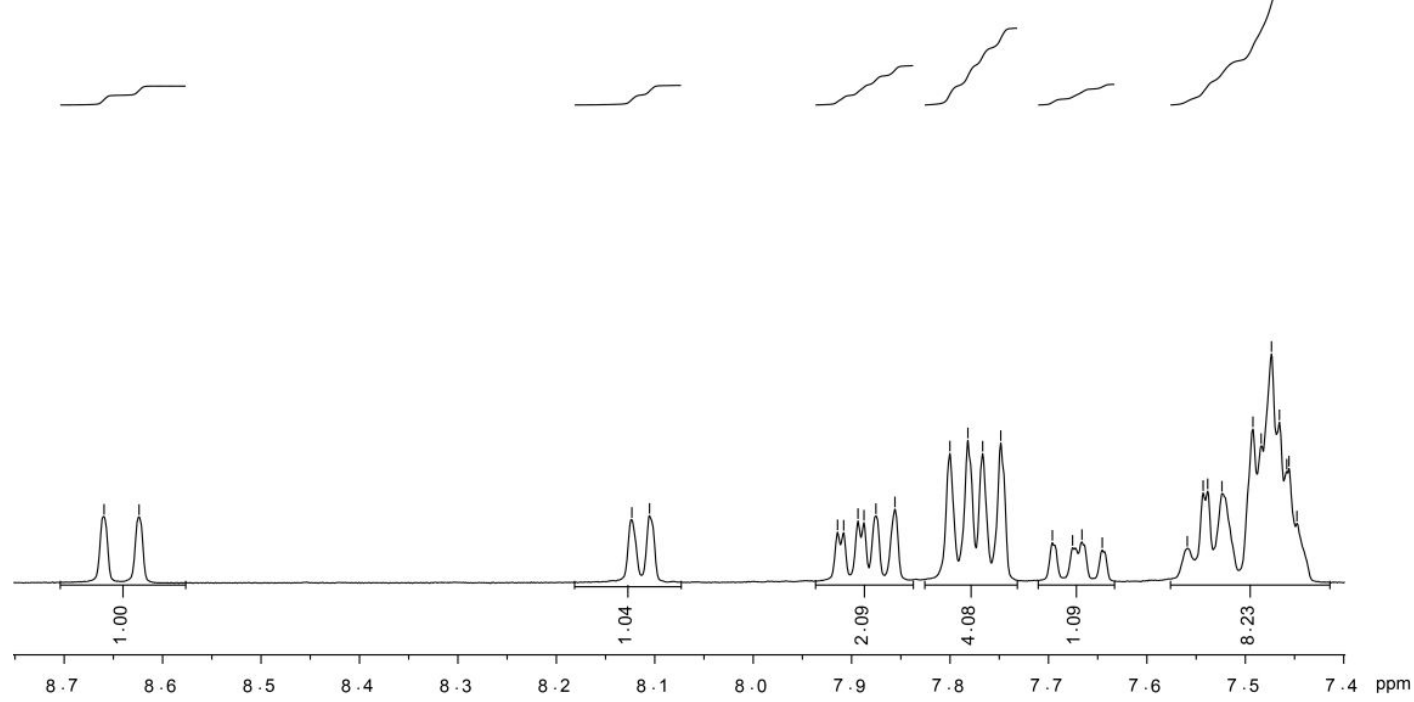

Figure S1. ${ }^{1} \mathrm{H}$ NMR spectrum of DBFSPS 

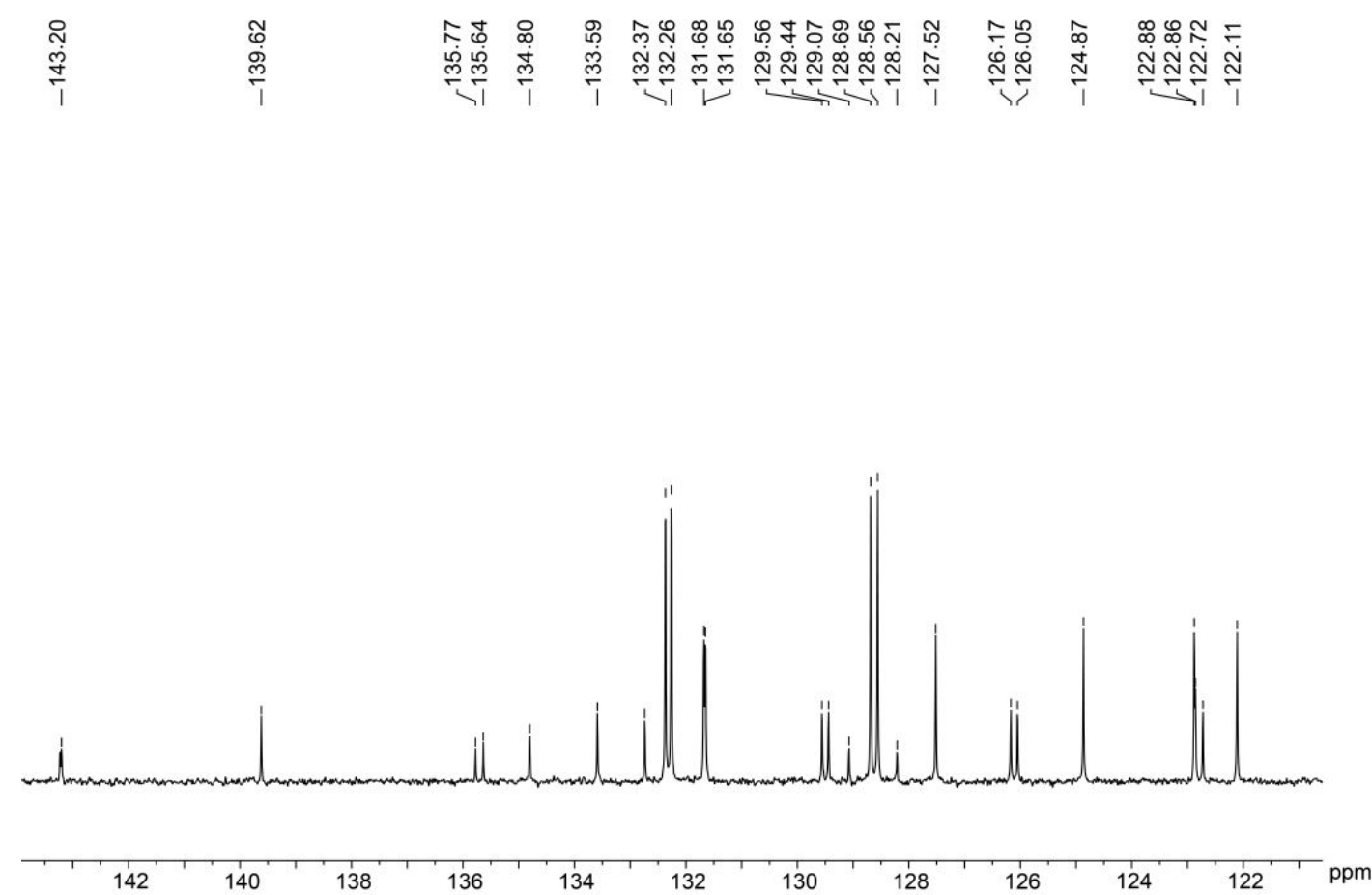

Figure S2. ${ }^{13} \mathrm{C}$ NMR spectrum of DBFSPS.

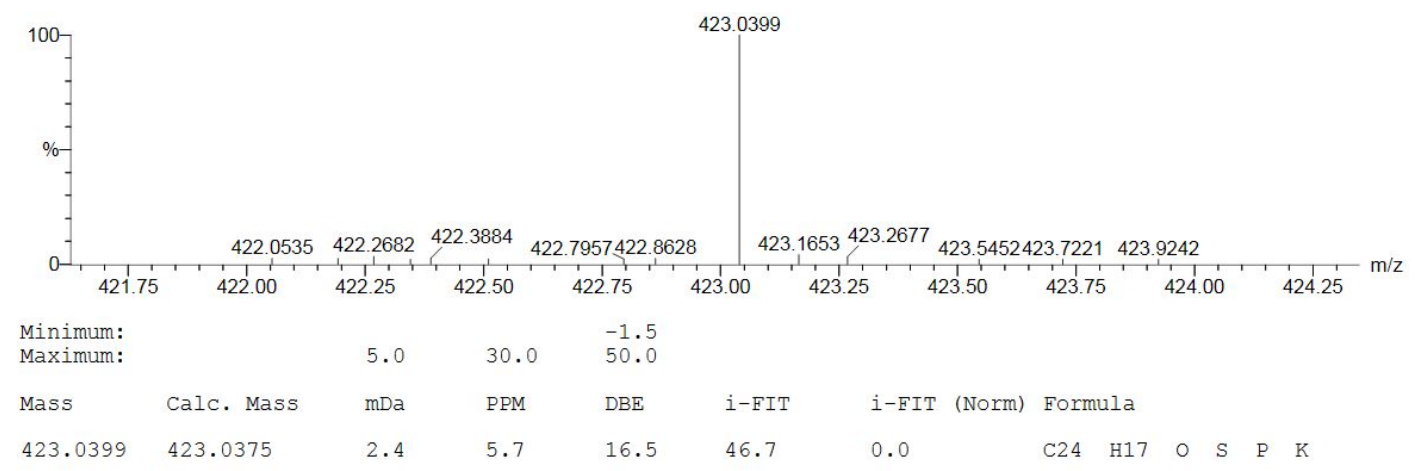

Figure S3. HRMS spectrum of DBFSPS.

\section{Synthesis of dibenzo[b, d]thiophen-2-yldiphenylphosphine sulfide (DBTSPS)}

DBTSPS was prepared under the identical synthetic conditions described in the preparation of DBFSPS using 2-bromodibenzothiophen (2.6 g, $10.0 \mathrm{mmol}), n$-BuLi (7.5 mL, $12 \mathrm{mmol}, 1.6 \mathrm{M}$, in hexane), diphenylphosphine chloride $(2.0 \mathrm{~mL}, 10.81 \mathrm{mmol})$ and sulfur $(1.0 \mathrm{~g}, 30 \mathrm{mmol})$. Yield: 1.8 g of white power $(45.1 \%) . \mathrm{Mp}: 136^{\circ} \mathrm{C} .{ }^{1} \mathrm{H}$ NMR $\left(400 \mathrm{MHz}, \mathrm{CDCl}_{3}, \mathrm{ppm}\right) \delta 8.66(\mathrm{~d}, J=12.0 \mathrm{~Hz}$, 1H), $8.12(\mathrm{~d}, J=8.0 \mathrm{~Hz}, 1 \mathrm{H}), 7.91(\mathrm{~d}, J=12.0 \mathrm{~Hz}, 1 \mathrm{H}), 7.87(\mathrm{~d}, J=8 \mathrm{~Hz}, 1 \mathrm{H}), 7.78(\mathrm{~m}, 4 \mathrm{H}), 7.70$ (m, 1H), $7.54(\mathrm{~m}, 8 \mathrm{H}) ;{ }^{13} \mathrm{C} \mathrm{NMR}\left(100 \mathrm{MHz}, \mathrm{CDCl}_{3}, \mathrm{ppm}\right) \delta 143.20,139.62,135.78,135.64,134.80$, $133.59,132.74,132.37,132.26,131.68,131.65,129.56,129.44,129.07,128.69,128.56,128.21$, 127.52, 126.17, 126.05, 124.87, 122.88, 122.73, 122.11; HRMS (EI): $\mathrm{m} / \mathrm{z}$ calcd for $\mathrm{C}_{24} \mathrm{H}_{18} \mathrm{PS}_{2}$ $[\mathrm{M}+\mathrm{H}]^{+}: 401.0588$; found: 401.0594 . 


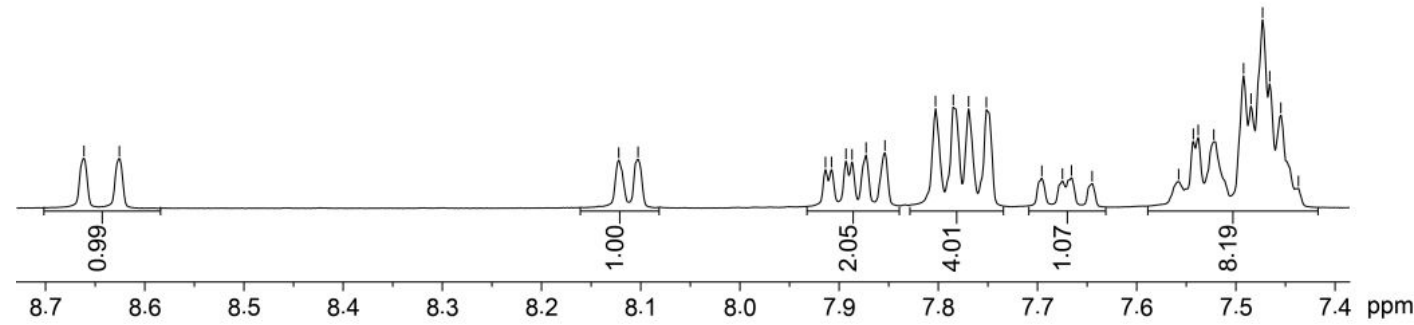

Figure S4. ${ }^{1} \mathrm{H}$ NMR spectrum of DBTSPS.

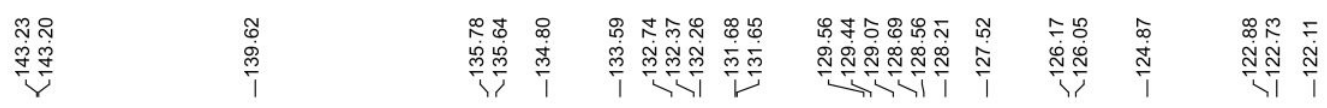

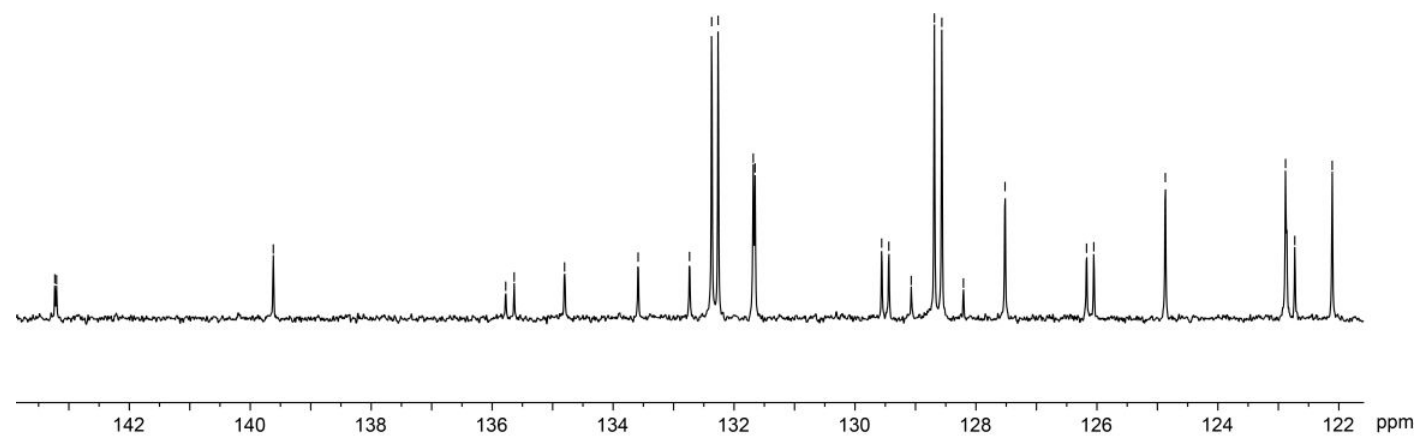

Figure S5. ${ }^{13} \mathrm{C}$ NMR spectrum of DBTSPS. 


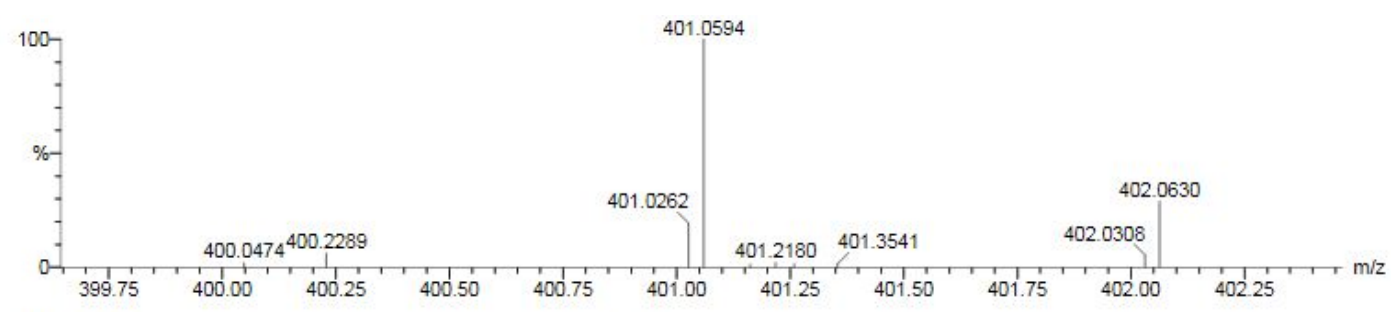

\begin{tabular}{|c|c|c|c|c|c|c|c|c|}
\hline $\begin{array}{l}\text { Minimum: } \\
\text { Maximum: }\end{array}$ & & 5.0 & 30.0 & $\begin{array}{l}-1.5 \\
50.0\end{array}$ & & & & \\
\hline Mass & Calc. Mass & $\mathrm{mDa}$ & PPM & DBE & i-FIT & i-FIT (Norm) & Formula & \\
\hline 401.0594 & 401.0588 & 0.6 & 1.5 & 16.5 & 42.4 & 0.0 & $\mathrm{C} 24 \mathrm{H} 18$ & s2 \\
\hline
\end{tabular}

Figure S6. HRMS spectrum of DBTSPS.

Synthesis of dibenzo[b, d]furan-2,8-diylbis(diphenylphosphine sulfide) (DBFDPS)

DBFDPS was prepared under the identical synthetic conditions described in the preparation of DBFSPS using 3,6-dibromodibenzofuran (3.3 g, 10.0 mmol), $n$-BuLi (13.8 mL, $22 \mathrm{mmol}, 1.6 \mathrm{M}$ in hexane), diphenylphosphine chloride $(3.7 \mathrm{~mL}, 19.8 \mathrm{mmol})$ and sulfur $(1.0 \mathrm{~g}, 30 \mathrm{mmol})$. Yield: 1.9 g of white power (31.7\%). Mp: $189^{\circ} \mathrm{C} .{ }^{1} \mathrm{H}$ NMR $\left(400 \mathrm{MHz}, \mathrm{CDCl}_{3}, \mathrm{ppm}\right) \delta 8.40(\mathrm{~d}, \mathrm{~J}=16 \mathrm{~Hz}, 2 \mathrm{H})$, $7.83(\mathrm{~m}, 2 \mathrm{H}), 7.74(\mathrm{~m}, 8 \mathrm{H}), 7.63(\mathrm{~d}, \mathrm{~J}=8.0 \mathrm{~Hz}, 2 \mathrm{H}), 7.53(\mathrm{~m}, 4 \mathrm{H}), 7.45(\mathrm{~m}, 8 \mathrm{H}) ;{ }^{13} \mathrm{C}$ NMR $(100$ $\left.\mathrm{MHz}, \mathrm{CDCl}_{3}, \mathrm{ppm}\right) \delta 158.46,133.38,132.52,132.30,132.19,132.11,131.98,131.79,131.76$, $128.76,128.64,128.39,127.52,126.22,126.09,123.92,123.94,112.10,111.96 ;$ HRMS (EI): m/z calcd for $\mathrm{C}_{36} \mathrm{H}_{27} \mathrm{OP}_{2} \mathrm{~S}_{2}[\mathrm{M}+\mathrm{H}]^{+}: 601.0979$; found:601.0985.

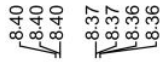

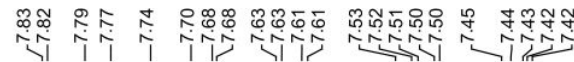
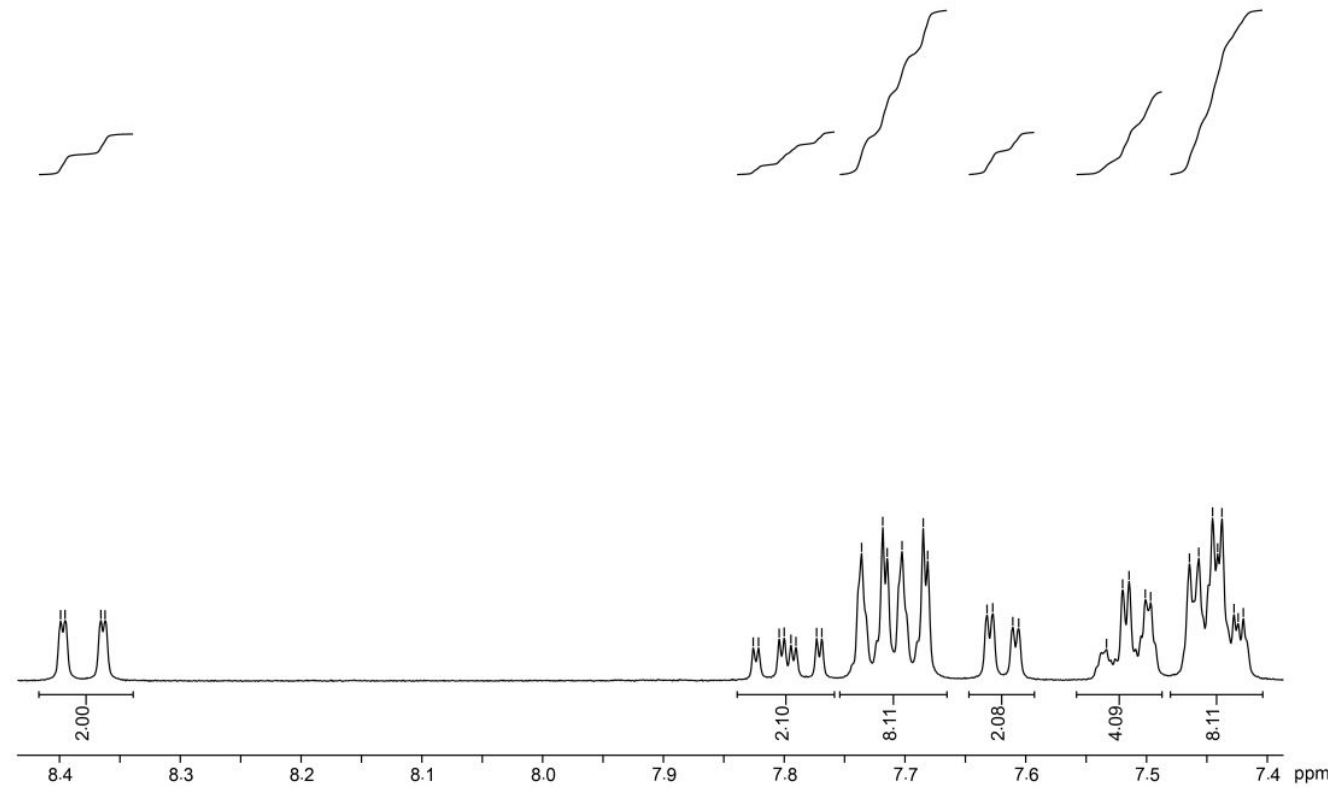

Figure S7. ${ }^{1} \mathrm{H}$ NMR spectrum of DBFDPS. 

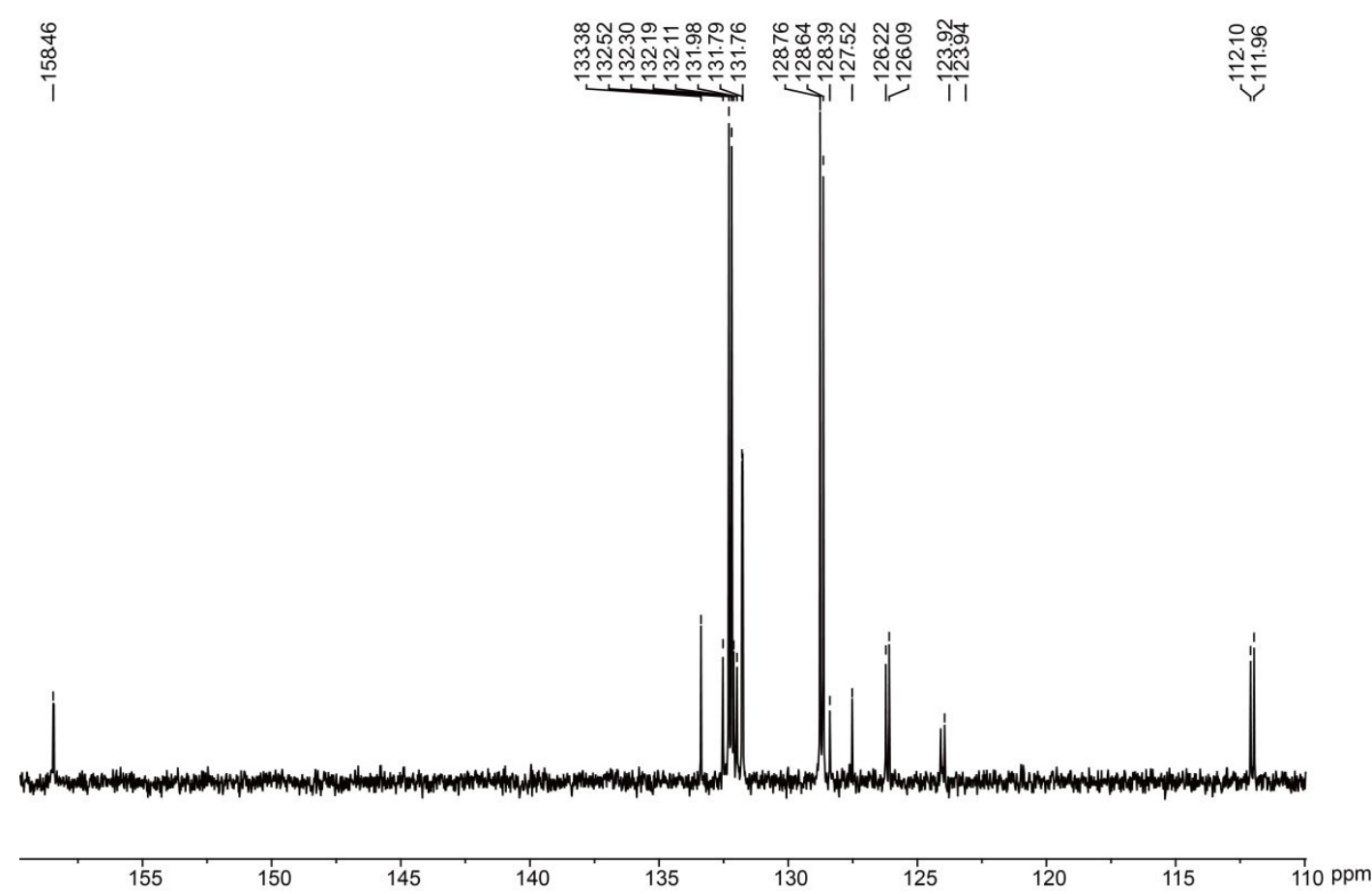

Figure S8. ${ }^{13} \mathrm{C}$ NMR spectrum of DBFDPS.

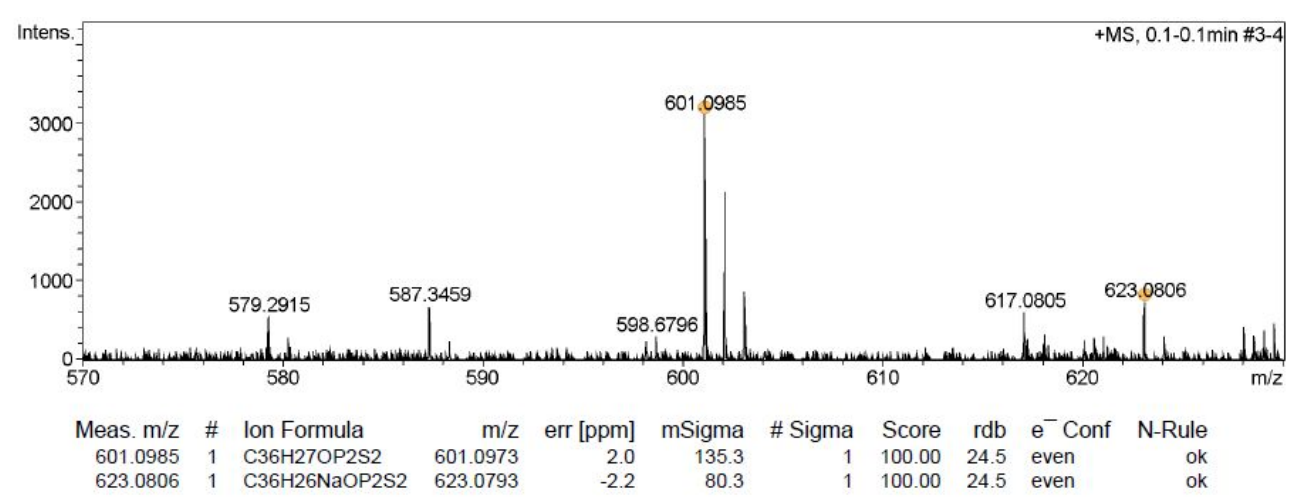

Figure S9. HRMS spectrum of DBFDPS.

\section{Synthesis of dibenzo[b,d]thiophene-2,8-diylbis(diphenylphosphine sulfide) (DBTDPS)}

DBTDPS was prepared under the identical synthetic conditions described in the preparation of DBFSPS using 3,6-dibromodibenzothiophen (1.4 g, $4.0 \mathrm{mmol}), n$-BuLi (5.5 mL, $8.8 \mathrm{mmol}, 1.6 \mathrm{M}$ in hexane), diphenylphosphine chloride $(1.7 \mathrm{~mL}, 10.0 \mathrm{mmol})$ and sulfur $(1.0 \mathrm{~g}, 30 \mathrm{mmol})$. Yield: $0.9 \mathrm{~g}$ of white power (36.6\%). Mp: $227^{\circ} \mathrm{C} .{ }^{1} \mathrm{H}$ NMR $\left(400 \mathrm{MHz}, \mathrm{CDCl}_{3}, \mathrm{ppm}\right) \delta 8.42(\mathrm{~d}, \mathrm{~J}=13.0$ $\mathrm{Hz}, 2 \mathrm{H}), 7.94(\mathrm{~d}, \mathrm{~J}=8.0 \mathrm{~Hz}, 2 \mathrm{H}), 7.82(\mathrm{~m}, 2 \mathrm{H}), 7.76(\mathrm{~m}, 8 \mathrm{H}), 7.55(\mathrm{~m}, 4 \mathrm{H}), 7.48(\mathrm{~m}, 8 \mathrm{H}) ;{ }^{13} \mathrm{C} \mathrm{NMR}$ $\left(100 \mathrm{MHz}, \mathrm{CDCl}_{3}, \mathrm{ppm}\right) \delta 143.30,134.93,134.78,133.18,132.33,132.22,131.78,131.75,130.46$, 130.34, 130.09, 129.23, 128.72, 128.60, 126.23, 126.11, 123.11, 122.98; HRMS (EI): m/z calcd for $\mathrm{C}_{36} \mathrm{H}_{27} \mathrm{P}_{2} \mathrm{~S}_{3}[\mathrm{M}+\mathrm{H}]^{+}:$617.0777; found: 617.0755 . 


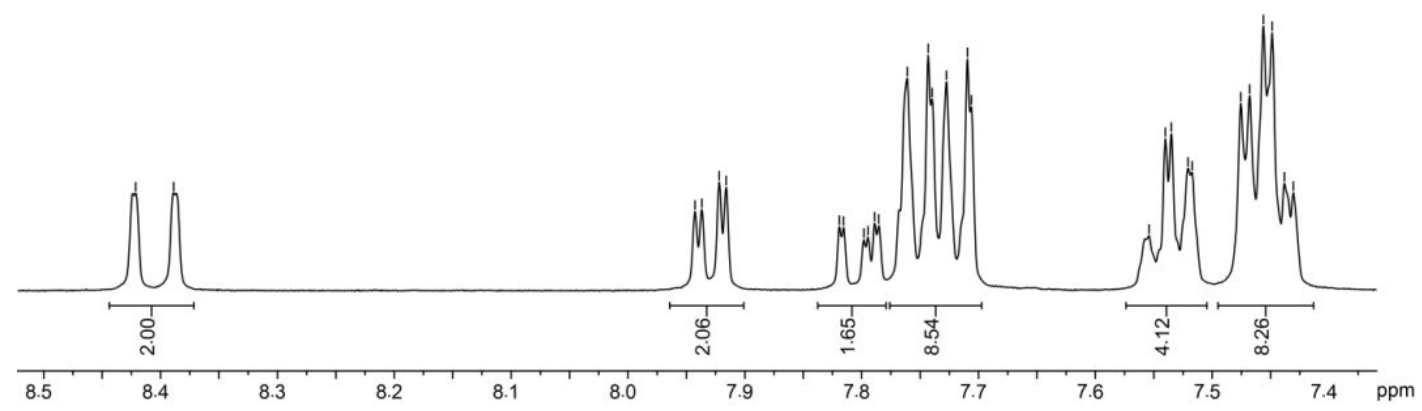

Figure S10. ${ }^{1} \mathrm{H}$ NMR spectrum of DBTDPS.
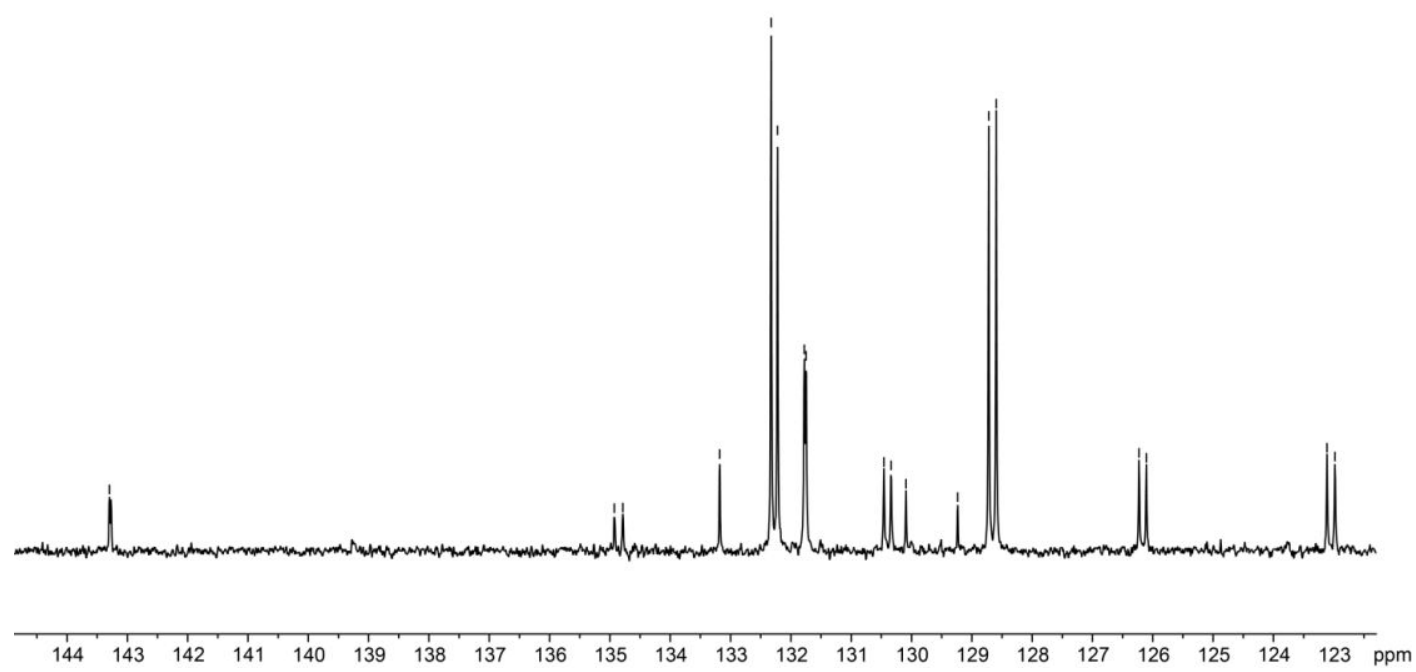

Figure S11. ${ }^{13} \mathrm{C}$ NMR spectrum of DBTDPS. 


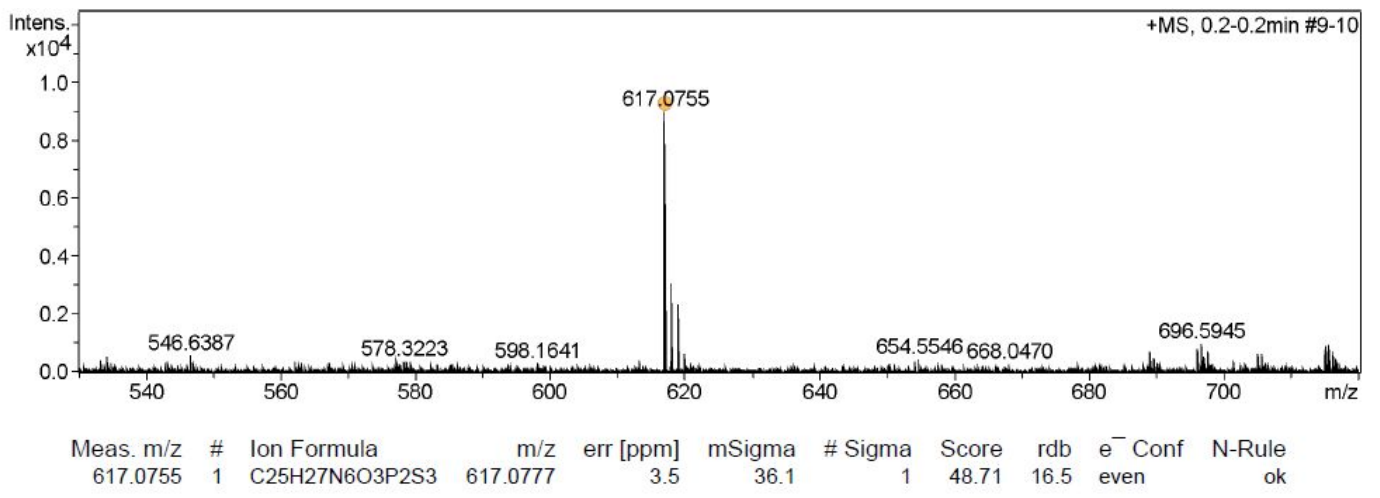

Figure S12. HRMS spectrum of DBTDPS. 


\section{Single crystal analysis}

Single crystals were grown by slow evaporation of a combined $\mathrm{CH}_{2} \mathrm{Cl}_{2}$ and ethanol solution at room temperature. X-ray crystallography was carried out on a Bruker SMART APEX-II CCD diffractometer with graphite monochromated Mo-K $\alpha$ radiation at $296 \mathrm{~K}$. The crystal structures were analyzed by Diamond 3.2 software and the structure data were summarized in Table S1.

Table S1. Crystallographic data of DBFSPS, DBTSPS, DBFDPS and DBTDPS single crystals.

\begin{tabular}{|c|c|c|c|c|}
\hline Compound & DBFSPS & DBTSPS & DBFDPS & DBTDPS \\
\hline Empirical formula & $\mathrm{C}_{24} \mathrm{H}_{17} \mathrm{OPS}$ & $\mathrm{C}_{24} \mathrm{H}_{17} \mathrm{PS}_{2}$ & $\mathrm{C}_{36} \mathrm{H}_{26} \mathrm{OP}_{2} \mathrm{~S}_{2}$ & $\mathrm{C}_{36} \mathrm{H}_{26} \mathrm{P}_{2} \mathrm{~S}_{3}$ \\
\hline Formula weight $\left(\mathrm{g} \mathrm{mol}^{-1}\right)$ & 384.4328 & 400.4938 & 600.6705 & 616.7315 \\
\hline Crstyal color & colorless & colorless & colorless & colorless \\
\hline Wavelength $(\AA)$ & 0.71073 & 0.71073 & 0.71073 & 0.71073 \\
\hline Crystal system & Triclinic & Triclinic & monoclinic & monoclinic \\
\hline Space group & $\mathrm{P}-1$ & P-1 & $\mathrm{P} 12_{1} / \mathrm{c} 1$ & P1 2, 1 1 \\
\hline$a,(\AA)$ & $9.4994(10)$ & $9.0561(15)$ & $13.488(3)$ & $9.7606(8)$ \\
\hline$b,(\AA ̊)$ & $9.8220(11)$ & $10.0977(17)$ & $25.932(5)$ & $26.598(2)$ \\
\hline$c,(\AA)$ & $22.167(3)$ & $11.1714(18)$ & $9.1108(18)$ & $12.014(1)$ \\
\hline$\alpha,(\mathrm{deg})$ & $92.358(3)$ & $85.238(3)$ & 90 & 90 \\
\hline$\beta,(\operatorname{deg})$ & $101.501(3)$ & $80.069(3)$ & $104.569(5)$ & $97.436(2)$ \\
\hline$\gamma,(\operatorname{deg})$ & $103.990(3)$ & $78.495(4)$ & 90 & 90 \\
\hline volume, $\left(\AA^{3}\right)$ & 1957.9(4) & $984.8(3)$ & $3084.2(10)$ & $3092.8(4)$ \\
\hline$Z$ & 2 & 2 & 4 & 4 \\
\hline Density, $\left(\mathrm{g} \mathrm{cm}^{-3}\right)$ & 1.304 & 1.351 & 1.294 & 1.324 \\
\hline$\mu,\left(\mathrm{mm}^{-1}\right)$ & 0.258 & 0.358 & 0.304 & 0.368 \\
\hline$F(000)$ & 800.0 & 416.0 & 1248.0 & 1280.0 \\
\hline$h_{\max }, k_{\max }, l_{\max }$ & $12,13,29$ & $15,16,18$ & $19,38,13$ & $14,38,17$ \\
\hline CCDC NO. & 1919035 & 1919050 & 1919023 & 1919024 \\
\hline
\end{tabular}




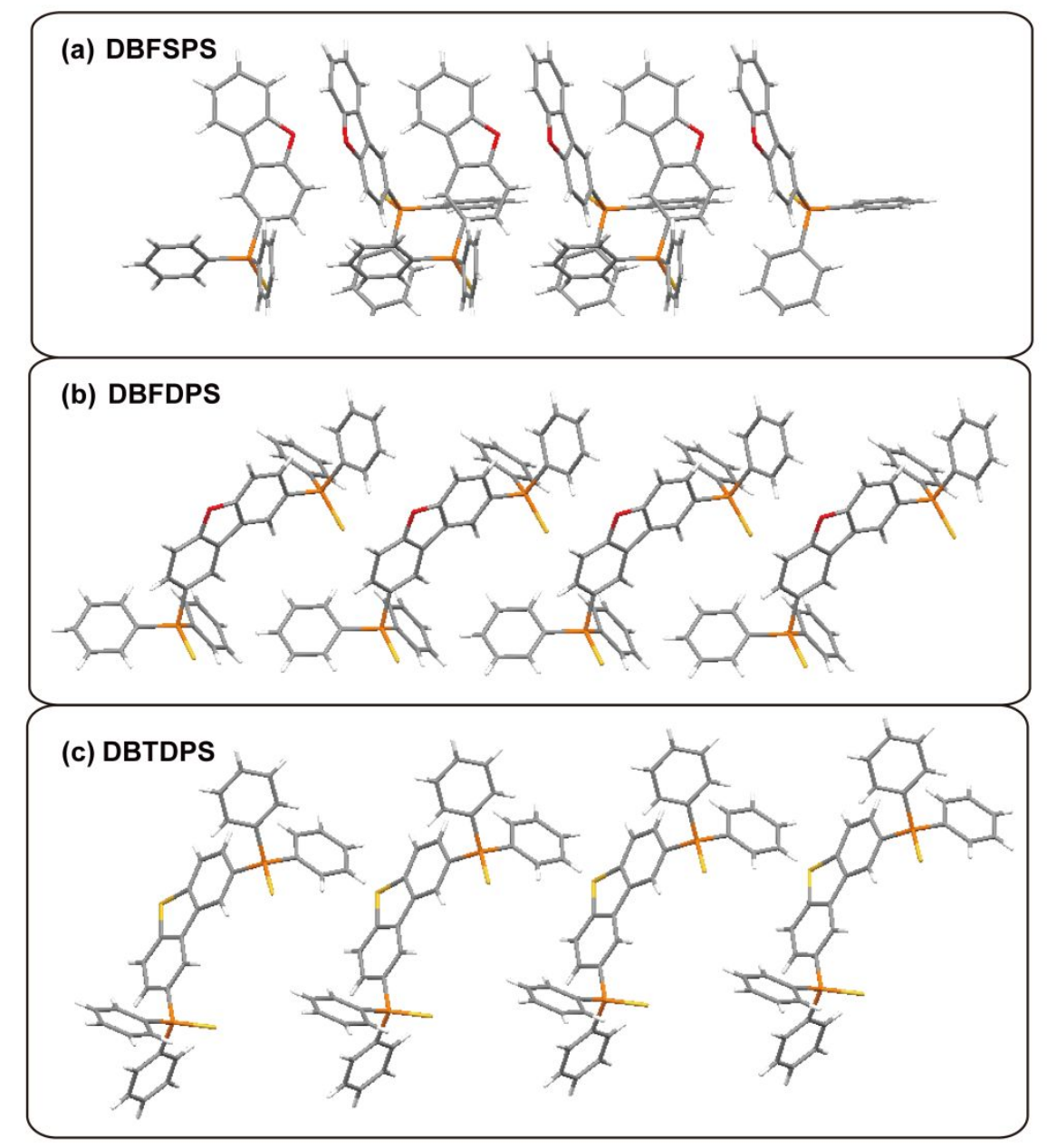

Figure S13. Molecular packing mode of (a) DBFSPS, (b) DBFDPS and (c) DBTDPS. 


\section{Thermal properties}

Thermogravimetric analysis (TGA) and differential scanning calorimetry (DSC) were performed to investigate the thermal properties of the compounds. TGA measurements were conducted on a Netzsch STA2500 thermogravimetric analyses at a heating rate of $10^{\circ} \mathrm{C} \mathrm{min}^{-1}$ and a nitrogen flow rate of $50 \mathrm{~cm}^{3} \mathrm{~min}^{-1}$. DSC analyses were performed on a Netzsch DSC214 Polyma instrument under a heating rate of $10^{\circ} \mathrm{C} \mathrm{min}-1$ and a nitrogen flow rate of $20 \mathrm{~cm}^{3} \mathrm{~min}^{-1}$.
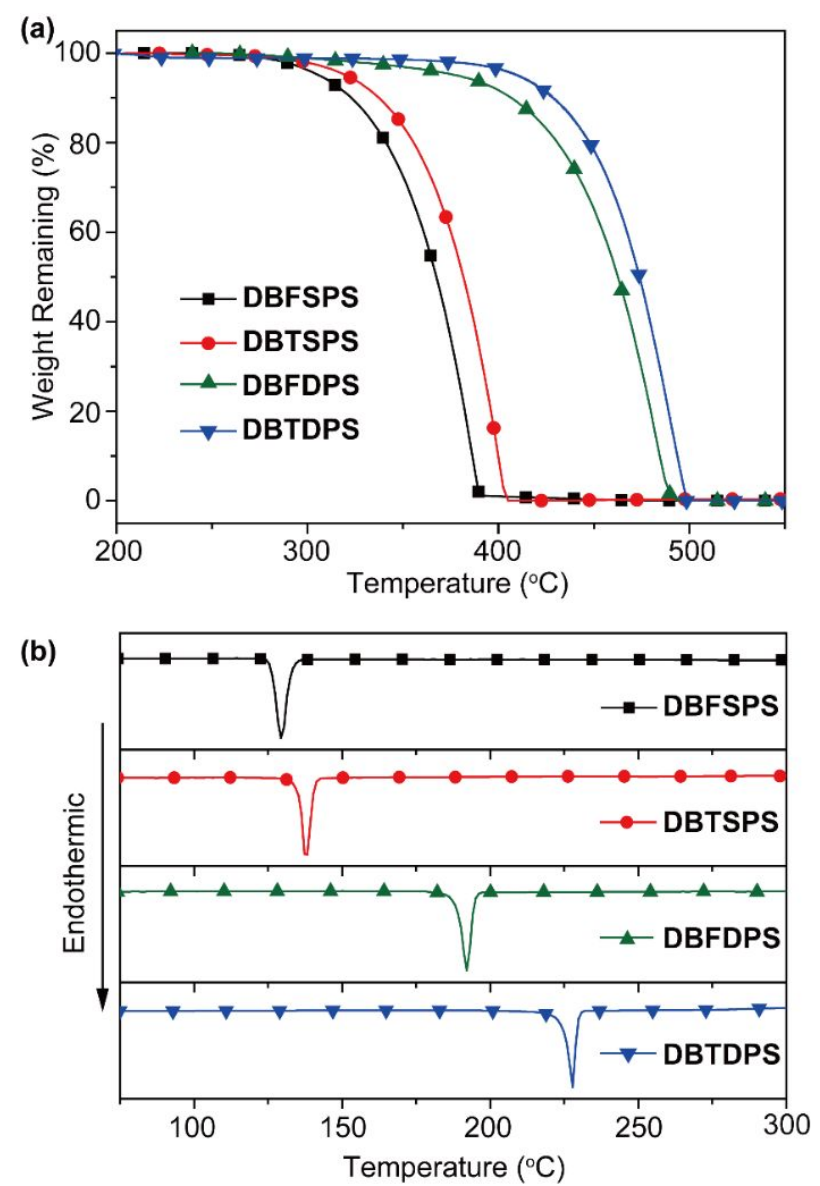

Figure S14. (a) TGA and (b) DSC curves of DBFSPS, DBTSPS, DBFDPS and DBTDPS. 


\section{Morphology properties}

Atomic force microscopy (AFM) measurements were carried out at room temperature using a Bruker Dimension Icon AFM equipped with Scanasyst-Air peak force tapping mode AFM tips from Bruker. The thin films were prepared through vacuum-deposition on glass substrates under the identical conditions as that in phosphorescent organic light emitting diode (PhOLED) device fabrication.
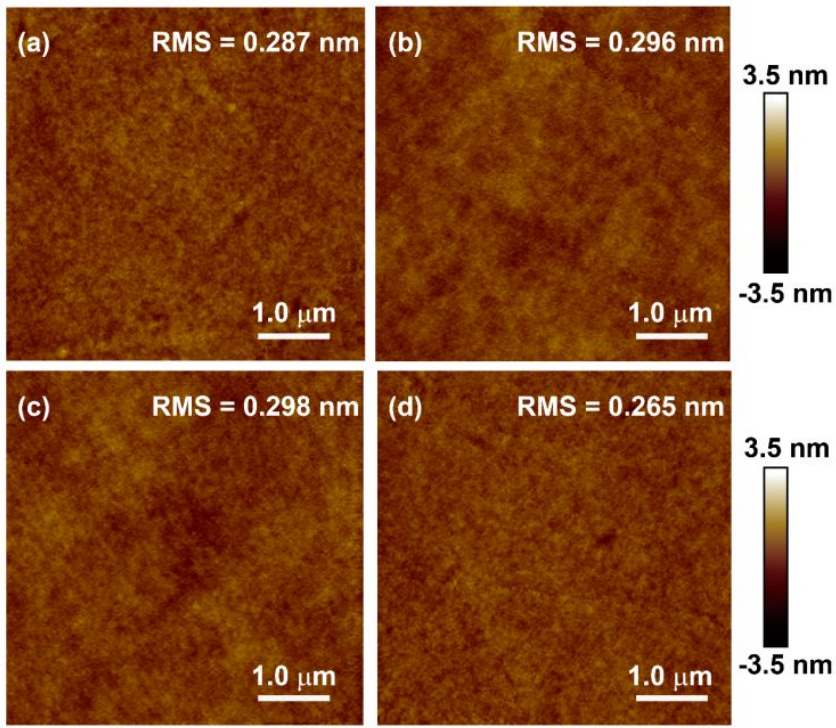

Figure S15. AFM height images $\left(5 \times 5 \mu \mathrm{m}^{2}\right)$ and root-mean-square (RMS) roughness of vacuumdeposited (a) DBFSPS, (b) DBTSPS, (c) DBFDPS and (d) DBTDPS films (100 nm thick) on glass substrates. 


\section{Optical properties}

Ultraviolet-visible (UV-Vis) and fluorescence spectra were recorded on a Jasco V-750 spectrophotometer and Edinburgh FLS980, respectively. The phosphorescence spectra of the compounds in $\mathrm{CH}_{2} \mathrm{Cl}_{2}$ were measured using a time-resolved Edinburgh FLS980 fluorescence spectrophotometer at $77 \mathrm{~K}$, with a $5 \mathrm{~ms}$ delay time after the excitation $(\lambda=290 \mathrm{~nm})$ using a microsecond flash lamp. The concentrations of the compound solutions (in $\mathrm{CH}_{2} \mathrm{Cl}_{2}$ ) were adjusted to be about $1 \times 10^{-5} \mathrm{~mol} \mathrm{~L}^{-1}$. The thin solid films made for optical property measurements were prepared by casting solution of the compounds on quartz substrates. The lifetimes $(\tau)$ of the luminescence were obtained by fitting the luminescent intensity decay curve $(I(\mathrm{t}))$ with a multiexponential decay function of

$$
I(\mathrm{t})=\sum_{i} A_{i} e^{-\frac{t}{\tau_{i}}}
$$

where $A_{i}$ and $\tau_{i}$ represent the amplitudes and lifetimes of the individual components for multiexponential decay profiles, respectively.

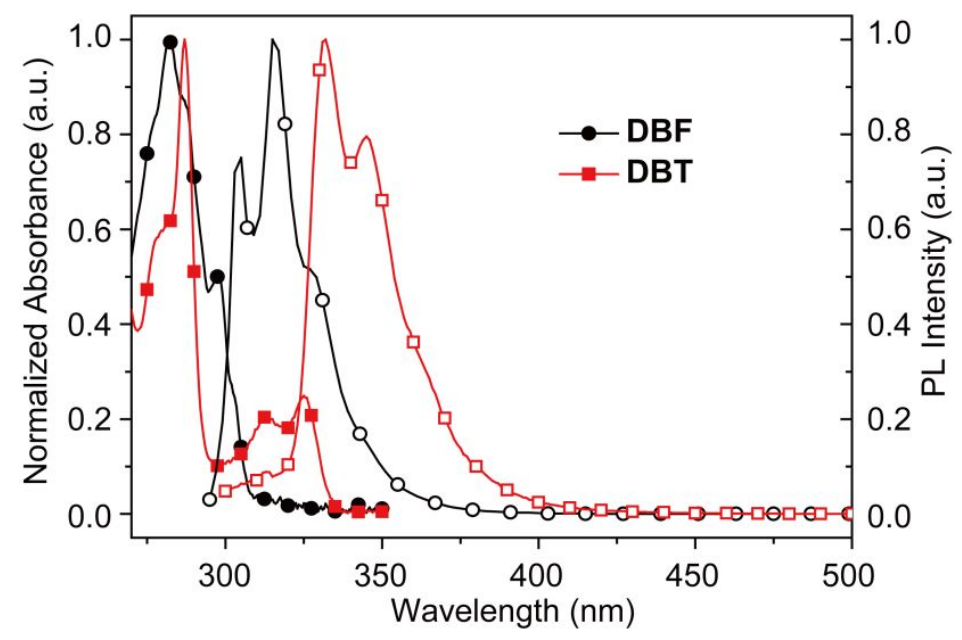

Figure S16. Absorption and PL (excited at $286 \mathrm{~nm})$ spectra of DBF and DBT in dilute $\left(1 \times 10^{-5} \mathrm{~mol}\right.$ $\left.\mathrm{L}^{-1}\right) \mathrm{CH}_{2} \mathrm{Cl}_{2}$ solution. 


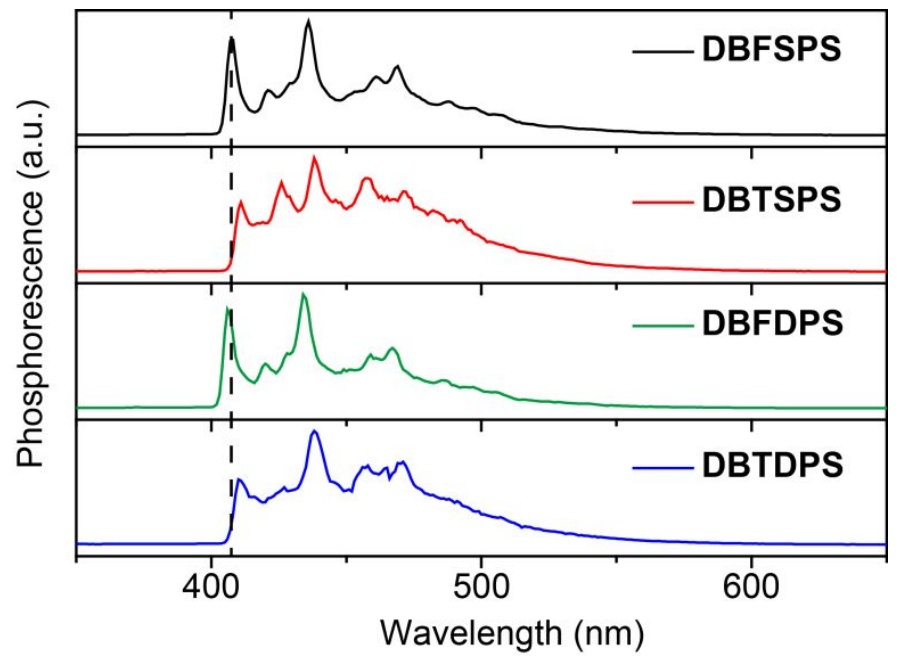

Figure S17. Phosphorescence spectra (excited at $290 \mathrm{~nm}$ ) of DBFSPS, DBTSPS, DBFDPS and DBTDPS at $77 \mathrm{~K}$ in $\mathrm{CH}_{2} \mathrm{Cl}_{2}$ glass with a delay time of $5 \mathrm{~ms}$.

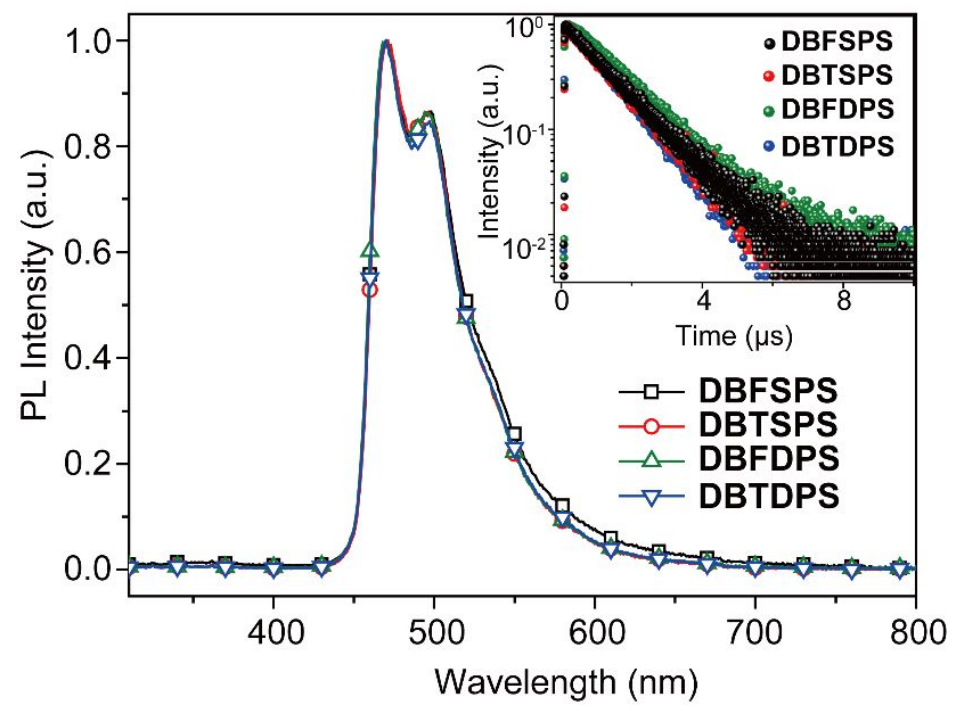

Figure S18. Photoluminescence (PL) spectra and decay profiles (inset) of the FIrpic-doped (15 wt \%) DBFSPS, DBTSPS, DBFDPS and DBTDPS thin films excited at $290 \mathrm{~nm}$. 


\section{DFT calculations}

Theoretical calculations were performed on Gaussian 09 program with the Becke's threeparameter exchange functional along with the Lee-Yang Parr's correlation functional (B3LYP) using 6-31G (d) basis sets. ${ }^{1}$ The geometries at the ground state $\left(\mathrm{S}_{0}\right)$ and the lowest triplet excited state $\left(T_{1}\right)$ were fully optimized by spin-restricted and spin-unrestricted DFT calculations at the B3LYP/6-31G (d) level, respectively. The optimized geometry at the lowest singlet excited state $\left(\mathrm{S}_{1}\right)$ was obtained by TD-DFT calculations at the same functional and basis set. Vibrational frequency calculations were subsequently carried out to confirm that all these optimized structures are corresponding to the minima on the potential energy surfaces. The balance of charge injection and transportation are crucial for optoelectronic devices; therefore, it is important to investigate the ionization potentials (IPs), hole extraction potentials (HEPs), electronic affinities (EAs), electron extraction potentials (EEPs) and reorganization energies $(\lambda)$ of optoelectronic molecules to evaluate the electronic properties. ${ }^{2}$

Table S2. B3LYP/6-31G(d) predicted ionization potential (IP), hole extraction potential (HEP), electronic affinity (EA), electron extraction potential (EEP), relaxation energies $\left(\lambda^{+}, \lambda_{1}, \lambda^{-}\right.$and $\left.\lambda_{2}\right)$, reorganization energies $\left(\lambda_{\text {hole }}\right.$ and $\lambda_{\text {electron }}$ ), highest occupied molecular orbital (HOMO)/lowest unoccupied molecular orbital (LUMO) energy levels (eV), energy gaps $\left(E_{\mathrm{g}}, \mathrm{eV}\right)$ and triplet energies $\left(E_{\mathrm{T}}, \mathrm{eV}\right)$ of DBFSPS, DBTSPS, DBFDPS and DBTDPS.

\begin{tabular}{cccccccccccccccc}
\hline Compound & IP & HEP & EA & EEP & $\lambda^{+}$ & $\lambda_{1}$ & $\lambda^{-}$ & $\lambda_{2}$ & $\lambda_{\mathrm{h}}$ & $\lambda_{\mathrm{e}}$ & HOMO/LUMO & $\boldsymbol{E}_{\mathrm{g}}$ & $\boldsymbol{E}_{\mathrm{T}}$ \\
\hline DBFSPS & 7.36 & 6.66 & -0.13 & 0.15 & 0.33 & 0.38 & 0.15 & 0.14 & 0.70 & 0.28 & $-5.78 /-1.19$ & 4.59 & 3.01 \\
\hline DBTSPS & 7.22 & 6.66 & -0.10 & 0.18 & 0.27 & 0.30 & 0.14 & 0.15 & 0.56 & 0.28 & $-5.78 /-1.19$ & 4.59 & 3.00 \\
\hline DBFDPS & 7.08 & 6.61 & 0.22 & 0.46 & 0.25 & 0.22 & 0.12 & 0.13 & 0.47 & 0.24 & $-5.78 /-1.42$ & 4.36 & 3.00 \\
\hline DBTDPS & 7.05 & 6.59 & 0.22 & 0.49 & 0.25 & 0.21 & 0.12 & 0.15 & 0.46 & 0.27 & $-5.77 /-1.41$ & 4.36 & 2.97 \\
\hline
\end{tabular}




\section{Electrochemical properties}

Cyclic voltammogram (CV) measurements were performed at room temperature on a CHI660E system in a typical three-electrode cell with a working electrode (glass carbon), a reference electrode $\left(\mathrm{Ag} / \mathrm{Ag}^{+}\right.$, referenced against ferrocene/ferrocenium $\left.(\mathrm{FOC})\right)$, and a counter electrode (Pt wire) in an acetonitrile solution of tetrabutylammonium hexafluorophosphate $\left(\mathrm{Bu}_{4} \mathrm{NPF}_{6}\right)(0.1 \mathrm{M})$ at a sweeping rate of $100 \mathrm{mV} \mathrm{s}^{-1}$. HOMO energy level $\left(E_{\mathrm{HOMO}}\right)$ of the host materials are estimated based on the reference energy level of ferrocene ${ }^{3}$ ( $4.8 \mathrm{eV}$ below the vacuum) according to the Equations S2:

$$
E_{\text {HOMO }}=-\left[E_{\text {onset }}^{O x}-(0.04)\right]-4.8 \mathrm{eV}
$$

where the value of $0.04 \mathrm{~V}$ is the onset oxidative voltage of FOC $v s \mathrm{Ag} / \mathrm{Ag}^{+}$and $E_{\text {onset }}^{O x}$ is the onset potential of the oxidation. LUMO energy level ( $\left.E_{\mathrm{LUMO}}\right)$ was estimated by adding the optical bandgap $\left(E_{g}\right)$ to the corresponding HOMO energy level as in S3.

$$
E_{L U M O}=E_{\mathrm{g}}+E_{\text {НОмо }} \ldots \ldots \ldots \ldots \ldots . \mathrm{S} 3
$$

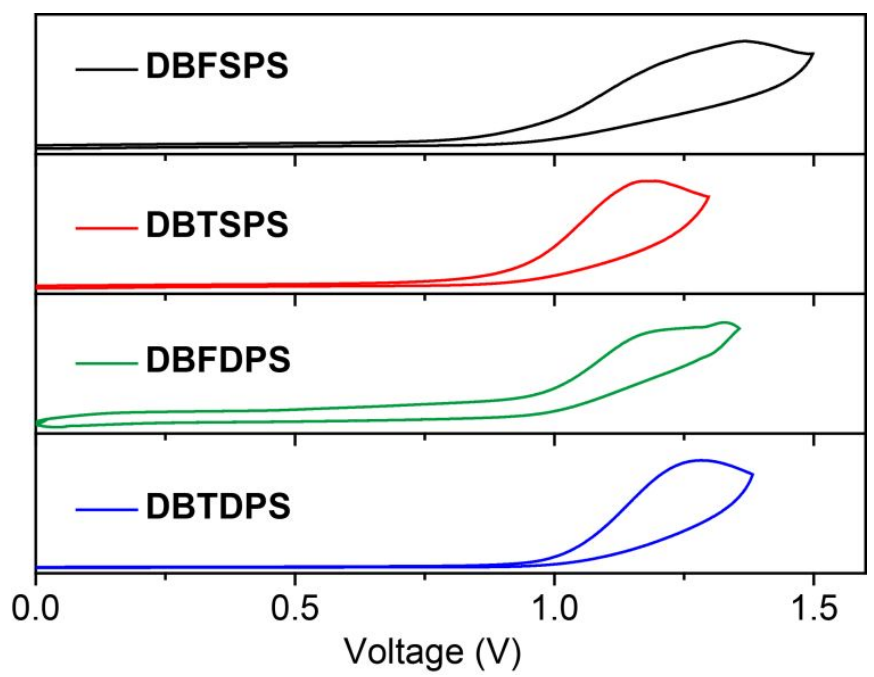

Figure S19. Cyclic voltammograms of DBFSPS, DBTSPS, DBFDPS and DBTDPS films deposited on the working electrodes. 


\section{Charge mobility}

In order to experimentally measure the hole and electron mobilities of DBFSPS, DBTSPS, DBFDPS and DBTDPS, the space charge limited current (SCLC) model was applied on hole-only and electron-only devices of ITO/MoO $(10 \mathrm{~nm}) /$ host $(100 \mathrm{~nm}) / \mathrm{MoO}_{\mathrm{x}}(10 \mathrm{~nm}) / \mathrm{Al}$ and ITO/LiF (1 $\mathrm{nm}) /$ host $(100 \mathrm{~nm}) / \mathrm{LiF}(1 \mathrm{~nm}) / \mathrm{Al}$, respectively. The current density $(J)$ in these devices follows the field-dependent space charge limited current (SCLC) model of Mott-Gurney law, ${ }^{4}$ which is given as:

$$
J_{S C L C}=\frac{9}{8} \varepsilon \varepsilon_{0} \mu_{0} \exp \left(0.89 \beta \sqrt{\frac{V}{d}}\right) \frac{V^{2}}{d^{3}}
$$

where $V$ is the electrical voltage, $d$ is the film thickness, $\mu_{0}$ is the mobility at zero field, $\varepsilon_{0}$ is the permittivity of free space $\left(8.854 \times 10^{-12} \mathrm{~F} \mathrm{~m}^{-1}\right)$, and $\varepsilon$ is the dielectric constant.

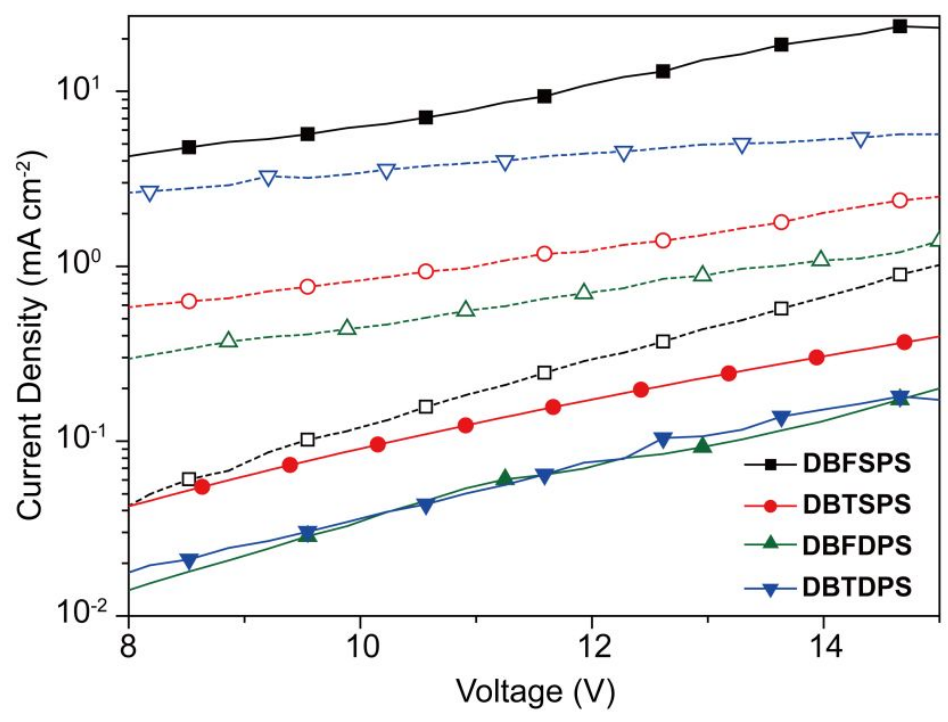

Figure S20. $J-V$ characteristics of the electron and hole transporting devices based on (a) DBFSPS, DBTSPS, DBFDPS and DBTDPS, respectively. Electron-only devices (solid symbol) and holeonly devices (open symbol), while lines are the fitting curves according to the field dependent SCLC model (Equation S4). 


\section{Device fabrications and measurements}

Typically, ITO-coated glass substrates were etched, patterned, and washed by ultrasonic with detergent, deionized water, acetone, and ethanol in turn. Organic layers were deposited by highvacuum $\left(10^{-6}\right.$ Torr) thermal evaporation at a rate of $0.1-0.2 \mathrm{~nm} \mathrm{~s}^{-1}$. The layer thickness and the deposition rate were monitored in situ by an oscillating quartz thickness monitor. The devices were measured after fabrication without encapsulation under ambient atmosphere at room temperature. The layer thickness and deposition rate $\left(1 \sim 2 \AA \mathrm{s}^{-1}\right)$ were monitored in situ by an oscillating quartz thickness monitor. Electroluminescent (EL) spectra of the devices were measured by JY SPEX CCD3000 spectrometer. The luminance-voltage and current-voltage characteristics were measured simultaneously with an optical power meter and a Keithley 2400 voltage current source. And the external quantum efficiency ${ }^{5}$ (EQE) was calculated by the following Equation:

$$
E Q E=\frac{\pi e \eta_{c d / A} \int \lambda p(\lambda) d \lambda}{h c K_{m} \int p(\lambda) \Phi(\lambda) d \lambda} \ldots \ldots \ldots \ldots \ldots \ldots \ldots \ldots . . . . . . . . . . . . .55
$$

where $\eta_{\mathrm{cd} / \mathrm{A}}$ is the current efficiency (cd/A); $h$ is the Planck constant; $c$ is the speed of light in vacuum; $\lambda$ is the wavelength (nm); $e$ is the electron charge; $p(\lambda)$ is relative electroluminescent intensity at each wavelength; $\Phi(\lambda)$ is the Commision International de l'Eclairage chromaticity (CIE) standard photopic luminous efficiency function; and $K_{m}$ is a constant of $683 \mathrm{~lm} / \mathrm{W}$.

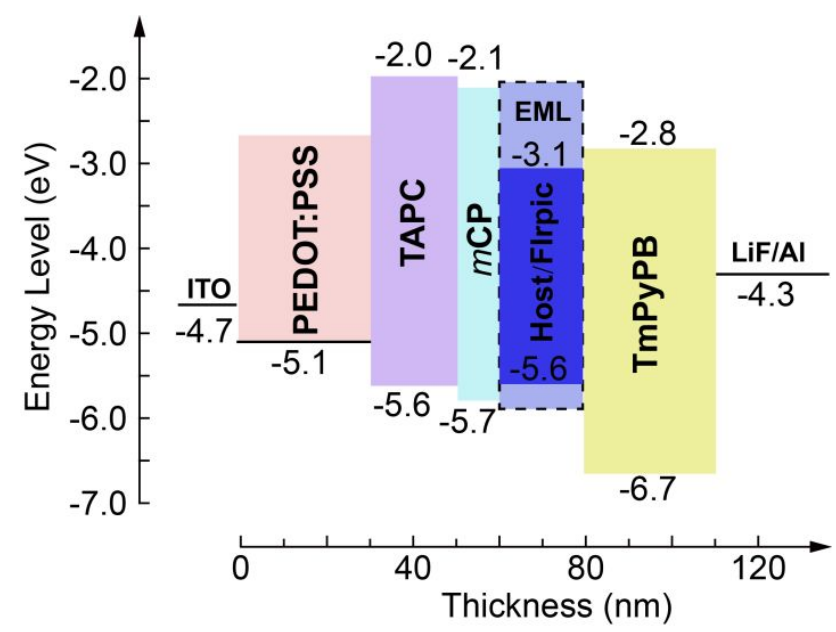

Figure S21. The device configuration and energy diagram of blue PhOLEDs using DBFSPS, DBTSPS, DBFDPS and DBTDPS as host materials (ITO/PEDOT: PSS (30 nm)/TAPC (20 $\mathrm{nm}) / m \mathrm{CP}(10 \mathrm{~nm}) /$ Host: FIrpic $(20 \mathrm{~nm}, 15 \%) / \mathrm{TmPyPB}(30 \mathrm{~nm}) / \mathrm{LiF}(1 \mathrm{~nm}) / \mathrm{Al}(100 \mathrm{~nm}))$. 
Table S3. Device performance of DBFSPS, DBTSPS, DBFDPS and DBTDPS.

\begin{tabular}{ccccccc}
\hline \multirow{2}{*}{ Host } & Operating & Maximum & Maximum & & \multicolumn{2}{c}{ Charge mobility $\left(\mathrm{cm}^{2} \mathrm{v}^{-1} \mathrm{~s}^{-1}\right)$} \\
\cline { 5 - 7 } & Voltage $(\mathrm{V})^{\mathrm{a}}$ & Efficiency $^{\mathrm{b}}$ & Luminescence $\left(\mathrm{cd} \mathrm{m}^{-2}\right)$ & & $\mu_{\mathrm{e}}$ & $\mu_{\mathrm{h}}$ \\
\hline DBFSPS & 3.9 & $21.6,15.3,10.9$ & 3843 & $(0.16,0.32)$ & $6.05 \times 10^{-7}$ & $6.38 \times 10^{-8}$ \\
DBTSPS & 3.7 & $27.8,21.4,14.1$ & 9400 & $(0.16,0.33)$ & $1.35 \times 10^{-8}$ & $4.31 \times 10^{-8}$ \\
DBFDPS & 3.8 & $18.3,11.4,9.2$ & 9362 & $(0.16,0.34)$ & $8.31 \times 10^{-9}$ & $2.44 \times 10^{-8}$ \\
DBTDPS & 3.7 & $24.0,20.0,12.2$ & 9818 & $(0.16,0.33)$ & $8.49 \times 10^{-9}$ & $3.76 \times 10^{-8}$ \\
\hline
\end{tabular}

${ }^{a}$ In the order of onset; ${ }^{b}$ In the order of $\mathrm{CE}\left(\mathrm{cd} \mathrm{A}^{-1}\right), \mathrm{PE}\left(\mathrm{lm} \mathrm{W} \mathrm{W}^{-1}\right)$ and EQE $(\%) ;{ }^{\mathrm{c}}$ Commission Internationale de L'Eclairage (CIE).

\section{References:}

(1) Yin, J.; Zhang, S.; Chen, R.; Ling, Q.; Huang, W. Carbazole Endcapped Heterofluorenes as Host Materials: Theoretical Study of Their Structural, Electronic, and Optical Properties. Phys. Chem. Chem. Phys. 2010, 12, 15448-15458.

(2) Yan, M.; Tao, Y.; Chen, R.; Zheng, C.; An, Z.; Huang, W. Computational Design and Selection of Optimal Building Blocks and Linking Topologies for Construction of High-Performance Host Materials. RSC Adv. 2012, 2, 7860-7867.

(3) Cardona, C. M.; Li, W.; Kaifer, A. E.; Stockdale, D.; Bazan, G. C. Electrochemical Considerations for Determining Absolute Frontier Orbital Energy Levels of Conjugated Polymers for Solar Cell Applications. Adv. Mater. 2011, 23, 2367-2371.

(4) Li, J.; Ding, D.; Tao, Y.; Wei, Y.; Chen, R.; Xie, L.; Huang, W.; Xu, H. A Significantly Twisted Spirocyclic Phosphine Oxide as a Universal Host for High-Efficiency Full-Color Thermally Activated Delayed Fluorescence Diodes. Adv. Mater. 2016, 28, 3122-3130.

(5) Tao, Y.; Xu, L.; Zhang, Z.; Chen, R.; Li, H.; Xu, H.; Zheng, C.; Huang, W. Achieving Optimal SelfAdaptivity for Dynamic Tuning of Organic Semiconductors through Resonance Engineering. J. Am. Chem. Soc. 2016, 138, 9655-9662. 